\title{
An Experiment in Conservative Modernity: Interwar Conservatism and Henry Ford's English Farms
}

\section{Kit Kowol}

\begin{abstract}
Between 1931 and 1947, the American industrialist Henry Ford financed a British agricultural experiment at the Fordson Estate in the Essex countryside. This article analyses the Fordson experiment as it developed from a limited attempt to test the merits of American farming methods into a wider model for remaking British industry and society. Focusing closely on Sir Percival Perry, a Conservative Party activist and Ford's partner in the venture, it explores the extent to which the experiment sought to harmonize modern technology with traditional patterns of life. In doing so, the article places the history of the Fordson Estate within the paradigm of interwar conservative modernity. By tracing Perry's participation within a network of industrial paternalist organizations and delineating his connection to the interwar conservative movement, the article demonstrates that conservative modernity stood largely outside formal party politics but was central to the praxis of interwar conservatism. It highlights an experimental, radical, and utopian form of conservative politics that aimed to foster conservative rural citizens.
\end{abstract}

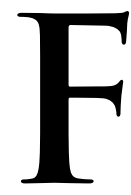

ew places differ so much as the Essex countryside and the Amazon rain forest: compare the gently undulating fields and mild temperate climate of Essex, a county bordering a great capital city, with the sticky stifling heat and human isolation of the Amazon's dark, foreboding jungle. Yet, for all their differences, during the 1930s both locations shared a number of similarities. In the midst of a global recession, their native industries-mixed farming in Essex and rubber tapping in Brazil—faced acute financial difficulties. As a result, both areas witnessed pronounced rural depopulation. In both locations, those left behind faced the gradual encroachment of modernity, ushering in changes that were altering traditional patterns of life. Moreover, both attracted the attention of the carmaker Henry Ford, the most famous industrialist of the era. In both Brazil and Essex, Ford embarked upon bold schemes designed to reverse these trends and show how the techniques of mass production, scientific management, and high wages that he had used to revolutionize the car industry could be adapted to serve the interests of agriculture and the rural community.

Kit Kowol is a lecturer in history at Christ Church, University of Oxford. Earlier versions of this article were presented at the North American Conference on British Studies, the Oxford Modern British History Seminar, and the University College History Seminar. The author would like to thank James Vernon, Richard Toye, Marc Stears, Clarisse Berthezène, Otto Saumarez Smith, Melissa Turoff, and the editors and peer reviewers of the Journal of British Studies for their comments and suggestions. The research was generously funded with grants from University College (Oxford) and the Henry Ford Museum. 
The first of these experiments, Fordlandia in Brazil, is relatively well known today thanks to Greg Grandin's Pulitzer Prize-winning book on the subject. ${ }^{1}$ Between 1927 and the end of the Second World War, Ford struggled in vain to create a rubber plantation in a location totally unsuited to the task. Indeed, the story of Fordlandia has proved so captivating that it even inspired a computer game that allows players to walk amidst the decaying remnants of saw mills and midwestern-style houses previously only visible to the most intrepid of tourists. ${ }^{2}$ By contrast, the less exotic setting, as well as a lack of accessible records, has ensured that Ford's agricultural activities in Essex have been all but forgotten. ${ }^{3}$

Accounts of what became known as the Fordson experiment are today relegated to a few pages in a book on the area's interwar history and a single chapter in a piece of Ford enthusiast literature. ${ }^{4}$ Nonetheless, for a time during the 1930s, a corner of Essex became popularly known as "Ford County" as a result of the automaker's innovative experiment in farming and land settlement. Developed in partnership with Sir Percival (later Lord) Perry - a businessman, Conservative activist, and the chairman of Ford Motors in the United Kingdom-the experiment's combination of mechanized farming, canny marketing, and profit sharing were, for a brief moment, held up as a model for British agriculture. It was examined closely by the Ministry of Agriculture as a potential example to be copied for the resettlement of the unemployed, and celebratory accounts of Ford and Perry's experiment filled the contemporary local, national, and international press. ${ }^{5}$ One article in the Observer even went so far as to suggest that Henry Ford be invited to become British Minister of Agriculture. ${ }^{6}$

As is the case with Fordlandia, Ford's Essex experiment can be read in a number of ways: a case study in Americanization, a history of agricultural commercialization, or simply a story of personal hubris. These frames of reference help make sense of the different elements that went into the creation and life of the Ford farms, which operated, in one form or another, between 1931 and 1972. However, the participation of a number of British Conservative activists in the scheme, the desire to restore an older imagined pattern of harmonious rural life, combined with faith in the role modern methods could play in achieving this, means that the Fordson experiment is best understood as a quintessential example of interwar conservative modernity.

A term originally employed by Alison Light, conservative modernity refers to what she saw as the dominant cultural mood of interwar Britain. ${ }^{7}$ For Light, in her study of the period's popular middle-class women's literature, this form of modernity was "Janus-faced." Capable of looking forward as well as back, conservative modernity

${ }^{1}$ Greg Grandin, Fordlandia: The Rise and Fall of Henry Ford's Forgotten Jungle City (London, 2010).

2 The Amazon Trail II, Minneapolis Educational Computing Corporation (Minneapolis, 1996), CD.

${ }^{3}$ The overwhelming majority of the estate's papers were accidently destroyed in the early 1990s.

${ }^{4}$ Ford R. Bryan, Beyond the Model T: The Other Ventures of Henry Ford (Detroit, 1990), 27-34; Fred Rideout, "The Ford Connection," in Boreham: History, Tales and Memories of an Essex Village, ed. Eleanor Burgess and Mary Rance (Lavenham, 1988), 106-12.

5 "Ford Purchases Boreham House," China Press (Shanghai), 25 May 1931; "Ford's Co-Operative Farms: Profits and Bonuses for Workers” West Australian (Perth), 12 April 1935.

6 "Land and Life: Mr. Henry Ford's Farm," Observer (London), 10 November 1935.

${ }^{7}$ Alison Light, Forever England: Femininity, Literature and Conservatism between the Wars (London, 1991).

${ }^{8}$ Ibid., 10. 
required a new type of conservatism and a new understanding of national character: domestic, feminine, and "English," conservative modernity acted as a counterpoint to a version of Englishness that was masculine, aggressive, and imperial, but which had fallen out of favor in the aftermath of the First World War.

As a number of historians have recently shown, such a cultural form of conservatism was also reflected in the attitude and actions of the Conservative Party in the 1920s and 1930s. As Philip Williamson's work on Stanley Baldwin demonstrates, conservative modernity was the hallmark of Baldwin's speechmaking and central to the construction of his own "gentlemanly" image. As Williamson notes, in Baldwin's rhetoric, the imagery of rural England and the idea that it was the nation's "spiritual home" was prominent. Yet Baldwin also suggested that this rural inheritance lived on, not in the outmoded aristocrat, but within the "capitalist individualist," the "company moderniser," and "the active citizen." Clarisse Berthezène's analysis of the Conservative Party's interwar training college at Ashridge Hall in Hertfordshire presents a similar story. Ashridge's location was deliberately selected for its pastoral setting and the spirit of "merrie England" it evoked. Reveling in rural elegies, Ashridge's participants nonetheless helped construct a new type of conservative "middle-brow" intellectual that embraced professional expertise. ${ }^{10}$ David Jarvis and David Thackeray have shown in their work on women and the Conservative Party a similar capacity to hold both past and future together in the party's gendered political appeal; for example, it embraced modern campaign communications directed at women while simultaneously emphasizing their domestic status. ${ }^{11}$

Such analyses of interwar conservatism have reshaped understanding of the dominant political force of interwar Britain. Rather than emphasizing the party's ability to construct an anti-Labour electoral bloc based on negative stereotypes of the working class - the central point of Ross McKibbin's influential work on the creation of a Conservative interwar "public" - these authors have instead stressed interwar conservatism's positive appeal and its ability to attract multiple political, social, denominational, and regional groups. ${ }^{12}$ Building on this work, this article offers a case study in interwar Conservative politics and the conservative modernity it embraced. However, rather than examining rhetoric, political communication, or a cultural mood, by analyzing the politics of Ford's Essex estate this article examines conservative modernity and interwar conservatism in a physical form. In doing so, it treats the Fordson experiment as its founders intended: as an enacted conservative utopia for an imagined "modern" age. 259.

9 Philip Williamson, Stanley Baldwin: Conservative Leadership and National Values (Cambridge, 1999),

${ }^{10}$ Clarisse Berthezène, Training Minds for the War of Ideas: Ashridge College, the Conservative Party and the Cultural Politics of Britain, 1929-54 (Manchester, 2015).

${ }^{11}$ David Jarvis, "Mrs. Maggs and Betty: The Conservative Appeal to Women Voters in the 1920s," Twentieth Century British History 5, no. 2 (January 1994): 129-52; David Thackeray, Conservatism for the Democratic Age: Conservative Culture and the Challenge of Mass Politics in Early Twentieth Century England (Manchester, 2013), 135-48.

${ }^{12}$ Ross McKibbin, The Ideologies of Class (Oxford, 1990), 259-93. 


\section{MAKING THE FORDSON ESTATE}

The origins of Ford's Essex experiment lay in his long-standing belief in the virtue of workers combining agricultural and industrial labor. ${ }^{13}$ Such an arrangement, Ford believed, led to greater industrial and political stability. Workers who could grow their own food were less likely to engage in industrial agitation in periods of economic downturn. Likewise, Ford, who had himself grown up on a farm (though he personally disliked agricultural work) saw it as making men more productive, efficient, and proud when they returned to the factory. ${ }^{14}$

This idea of "machines in the garden" was particularly popular in early twentiethcentury America, but Ford's belief in the virtues of agricultural work was also shared by many interwar Conservatives. ${ }^{15}$ In the 1920s, Baldwin himself had been a keen supporter of relocating factories to the countryside, but Baldwin and the governments he dominated in the 1930s shifted their attention to questions of rural electrification and the development of Britain's road network as a means to draw the countryside closer in economics and experience to the city. Ford, however, persevered with the idea of transformation in the other direction: not taking the countryside to the city, but the city to countryside.

In 1929, Ford sought to combine the rural with the urban by choosing to locate his new car manufacturing plant at Dagenham on the marshes to the east of London. In addition to choosing a rural location for his new factory, Ford made allotments available for Dagenham employees to grow their own produce and raise their own animals, ensuring that they could share in a rural way of life. ${ }^{16}$ Yet, as with Fordlandia, the land identified by Ford was totally inappropriate for the task he had set for it. The man leading the development of the Dagenham plant, Sir Percival Perry, persuaded Ford to abandon the plan of creating allotments at Dagenham. Instead, Perry suggested that his employer purchase land further afield to be used, not for allotments, but to test another of Ford's pet beliefs: that mechanization and U.S. farming techniques could and should be applied to Britain as a means to raise agricultural productivity. ${ }^{17}$

The site Perry and Ford chose to test the merits of American agricultural practices was close to the village of Boreham, located thirty miles southeast of London. The estate they found at Boreham nonetheless failed to fit the image of the English countryside as a gentle, manicured, gardenlike idyll. Rather, like many others in England at that time, the estate was largely dilapidated. Having passed out of the hands of its long-standing owners, the aristocratic Kenyon family, the estate had been rented to a London financier more interested in sport than farming. Much of its land was, as a result, left rough and uncultivated, and many of its cottages were unfit for human habitation. ${ }^{18}$

${ }^{13}$ See also Howard P. Segal, Recasting the Machine Age: Henry Ford's Village Industries (Amherst, 2005).

${ }^{14}$ Reynold M. Wik, Henry Ford and Grass-Roots America (Ann Arbor, 1972), 191.

${ }^{15}$ Leo Marx, The Machine in the Garden: Technology and the Pastoral Ideal in America, (Oxford, 1964).

${ }^{16}$ Williamson, Stanley Baldwin, 245.

17 Allan Nevins and Frank Ernest Hill, "Interview with Lord Perry of Stock Harber [sic] by Allan Nevins and Frank Ernest Hill on March 28, 1952 at Nassau," 28 March 1952, Accession 834, Folder 1, 48, The Henry Ford (hereafter THF).

18 "The Boreham House Estate," 5 May 1931, Fairlane Subgroup, Accession 1, Box 185, Folder 7, THF. 
The site at Boreham was chosen because it contained the features necessary for Ford's vision of highly mechanized commercial farming. It was in a prime area for market gardening, one of the few forms of cultivation thought to be reliably profitable in the 1930s. ${ }^{19}$ Multiple nearby farms could be purchased to generate economies of scale. It was also just twenty-five miles from Dagenham and thus had a ready market for its products - though the idea that Dagenham workers would spend time on the land was quickly dropped when it became apparent to the estate's manager that factory workers had neither the necessary skills nor attitude for farming. ${ }^{20}$ With these advantages in mind, the estate, which included the elegant Georgian mansion, Boreham House, was purchased in 1931 for close to forty-five thousand pounds and renamed the Fordson Estate to echo the brand name of the Ford Motor Company's tractors. ${ }^{21}$

The transformation of the estate was slow. For every two pounds spent purchasing the land an additional one pound was needed to prepare it for cultivation. ${ }^{22}$ Ford's idiosyncratic demands also exacerbated existing problems: he insisted that no game birds be raised-a requirement on all his properties-and his desire to preserve trees was at odds with his demand to make farming as mechanically efficient as possible. $^{23}$ This, however, the estate eventually achieved. Fordson tractors were employed throughout to plough, cultivate, drill, and hoe the land, with Ford trucks used to transport goods to and from the market, though their noise and speed caused consternation among locals. ${ }^{24}$ Finally, Boreham House was transformed into a school for agricultural engineering. The school, however, accepted only men, a decision that reflected not only Ford's gendered view of farming but also his preference (and Perry's) for employing men on a "family wage" so as to maintain the traditional family structure. ${ }^{25}$ In the long run, though Ford's vision and beliefs played a vital role in the estate, it would be Perry who shaped the experiment's direction. Able to manipulate his employer's will and considerable resources, Perry engineered the farming venture as a means to demonstrate his own Conservative social and political philosophy.

Born in Bristol in 1878, Perry began his career in the motor trade in 1896 when he sold his stamp collection for a ticket to London and a chance to work for motoring pioneer Harry Lawson. ${ }^{26}$ After becoming friends with Ford a decade later, he was soon employed by the automaker, rising to managing director of Ford's British business, where he helped create the company's first English manufacturing plant at

${ }^{19}$ Alun Howkins, The Death of Rural England: A Social History of the Countryside since 1900 (London, 2003), 48-49.

${ }^{20}$ The National Archives (hereafter TNA), A. H. Hoare, "Fordson Estates, Ltd., Boreham, Essex," 16 April 1935, Ministry of Agriculture (hereafter MAF) 48/284.

21 "The Boreham House Estate."

${ }^{22}$ Percival L. D. Perry, Ten Years' Romance: An Agricultural Experiment (Boreham, 1945), 4.

${ }^{23}$ Charles Sorensen to Percival Perry, "Fordson Estates, Ltd," 29 October 1931, Charles E. Sorensen Records, Accession 38, Box 5, Benson Ford Research Center, THF.

24 "Glo'shire Debate on Unemployment," Gloucestershire Echo (Cheltenham), 28 March 1935.

${ }^{25}$ Lawrence H. Summers, "Did Henry Ford Pay Efficiency Wages?," Journal of Labor Economics 5, no. 4 (October 1987): 57-86, at 69; Aims of Industry, "Equal Pay": What It Is and What It Means (London, 1944).

${ }^{26}$ Richard Davenport-Hines, s.v., "Perry, Percival Lee Dewhurst, Baron Perry (1878-1956),” Oxford Dictionary of National Biography, http://www.oxforddnb.com/view/article/48100, accessed 27 April 2015. 
Trafford Park in Manchester. There, due to labor disputes in 1912-13, Perry instituted a policy of improved job security, reduced hours, and increased pay, which succeeded in breaking trade unionism and raising output. ${ }^{27}$ Indeed, Perry's efforts became the inspiration for Ford's famous five-dollar day program in Detroit. ${ }^{28}$ These actions and Perry's importance in the British business community ensured that he was employed in government during World War I, where he was among a number of industrialists-most famously Eric Geddes, Lord Rhondda, and Sir William Weir-brought into Whitehall to increase production. ${ }^{29}$ Perry, though, was dismayed by the inefficiencies of direct government intervention in economic matters, especially regarding prices. ${ }^{30}$ Returning to private industry after the war, Perry spent much of the early 1920s building Britain's first light industrial park, the Slough Trading Estate. ${ }^{31}$ This would go on to become the economic motor for Slough's subsequent suburban development and was railed against by many in Britain's rural preservationist movement, such as in John Betjeman's famous poem about the town. ${ }^{32}$ Having made his fortune in Slough, Perry returned to work at Ford Motors.

Politically, Perry exemplified the tradition of industrial paternalism. While many industrial paternalists had Liberal roots, by the 1930s the politics they represented were increasingly associated with the Conservative Party. Participating in anti-socialist organizations such as the strike-breaking Economic League and groups like the Industrial Welfare Association, prominent industrial paternalists included men like Imperial Chemical Industries chairman Harry McGowan, newspaper owner and consolidator Lord Illife, and the financier and hire-purchase advocate John Gibson Jarvie. ${ }^{33}$ Their firms in newer and lighter industries had bucked the trend of British interwar industrial decline. As a result, interwar industrial paternalists shared a powerful faith-common to their intellectual antecedents, the "new paternalists" of the mid-nineteenth century-in the civilizing power of modern industry. ${ }^{34}$ They believed that the ideas instituted within their own firms should be applied more widely to rescue Britain from an imagined moral and economic malaise. Industrial paternalists supported government attempts to rationalize and coordinate industrial production, providing social welfare through industry rather than the state, and encouraging high wages and profit sharing as a means to head off the growing power of trade unions.

These policies, along with the rhetoric of partnership, cooperation, and shared progress, were, of course, not far from those promoted by the Conservative Party

${ }^{27}$ Mira Wilkins and Frank Ernest Hill, American Business Abroad: Ford on Six Continents (Cambridge, 2011), 49 .

${ }^{28}$ Ford R. Bryan, Henry's Lieutenants (Detroit, 1993), 228.

29 Peter K. Cline, "Eric Geddes and the 'Experiment' with Businessmen in Government, 1915-1922," in Essays in Anti-Labour History: Responses to the Rise of Labour in Britain, ed. Kenneth D. Brown (London, 1974), 74-104.

${ }^{30}$ Percival Perry, "National Economy," Times (London), 3 December 1920.

${ }^{31}$ Burgess Wise David, Ford at Dagenham: The Rise and Fall of Detroit in Europe (Derby, 2001), 15.

32 David Matless, Landscape and Englishness (London, 1998), 35.

${ }^{33}$ Kit Kowol, "The Lost World of British Conservatism: The Radical Tory Tradition, 1939-1951" (PhD diss., University of Oxford, 2014), 21-25.

${ }_{34}$ Patrick Joyce, Work, Society, and Politics: The Culture of the Factory in Later Victorian England (Brighton, 1980), 135-53. 
during the interwar period, especially after the creation of the National Government in 1931. Moreover, as Stuart Ball has recently demonstrated, this was an era when the push for the rationalization of industry and the removal of excessive competition had gained widespread support within the Conservative Party as a means to relieve unemployment and offer an alternative to the socialist politics of nationalization. ${ }^{35}$ The National Government, for example, promoted numerous schemes for industrial consolidation, including in the vital steel and cotton industries. When seen together with government support for workplace insurance and health care, the actions of industrial paternalists in their own firms were less an alternative to the "New Conservatism" of the period, with its emphasis on the moral, the professional, and the unprovocative, but rather an attempt to push accepted conservative ideas and policies further and faster than legislation or government action would allow. ${ }^{36}$

Given Perry's interest in questions of wider political development, it is not surprising that he relished any opportunity to expand the ideological scope of Ford's experiment. His chance came in 1933, when Ford sent an edict from Detroit that this experiment in American farming techniques should be run on a cooperative basis-a statement that reveals the heterodox way in which cooperation could be understood during the period. ${ }^{37}$ With this instruction, which gave leeway for Perry to introduce any form of cooperation he saw fit, the experiment took on a social as well as agricultural element. Speaking to the estate's assembled workers in 1936, Perry clearly listed the objectives that guided the estate's operation:

1. The settlement of more people on the land.

2. The bringing of more land into cultivation.

3. To improve the lot of the agricultural worker by raising his wages, to better his standard of living and supply him with a more decent house to live in, and to increase his social well-being.

4. To produce more food from the soil of the country.

5. To increase the security of those who cultivate the soil and obtain for them a greater share of the fruits of their labour.

6. To apply more modern methods to Agriculture by the use of tractors and machinery, the scientific study of exhaustion and replenishment of soil, etc. ${ }^{38}$

These six aims demonstrate that the experiment had come a long way from Ford's trumpeting of American farming techniques. Indeed, by 1933 Ford had largely lost interest in the estate; the automaker was, by this stage, more concerned with the progress of Fordlandia and his other American agricultural ventures. Nor was the Fordson Estate a simple marketing exercise designed to show off Fordson tractors. The estate's enormous expense, which eventually came to almost half a million dollars, made it a very poor investment in advertising. ${ }^{39}$ Rather, for Perry,

35 Stuart Ball, "The Conservative Party, the Role of the State and the Politics of Protection, c.19181932," History 96, no. 323 (July 2011): 280-303, at 285-86.

${ }^{36}$ John Ramsden, The Age of Balfour and Baldwin, 1902-1940 (London, 1978), 206.

37 Daniel T. Rodgers, Atlantic Crossings: Social Politics in a Progressive Age (Cambridge, MA, 1998), 329.

38 "Speech by Sir Percival Perry," 25 April 1936, Engineering Laboratory Office Records Subgroup, 1943-1944, Accession 285, Box 2681, 9, THF.

${ }^{39}$ F. A. Thompson to B. J. Craig, "Fordson Estates," 18 April 1945, Fairlane Subgroup, Accession 1, Box 185, Folder 7, THF. 
it was an attempt to outline an alternative vision for British agriculture in which mechanization was a necessary but not sufficient part. Perry believed that the example of the Fordson Estate would show how new forms of land tenure, when embracing the cooperative ethic and high wages, could reverse rural depopulation and Britain's increasing reliance on overseas food imports. The experiment thus aimed to show how self-consciously enlightened industrialists like Perry could use mechanization and other modern techniques to create a more productive, vibrant, and harmonious rural society rather than a reduction in living standards and further exodus from the land. In short, it would do for agriculture and the rural community what he and other industrial paternalists believed their policies could do for the rest of British industry.

\section{THE FORDSON ESTATE IN CONTEXT}

Though historians, most notably Peter Mandler, have rightly critiqued the concept of interwar Englishness as a purely rural, nostalgic, and antimodern phenomenon, it is also true that interest in agriculture and the celebration of rural life remained far out of proportion to the economic importance of the rural economy in the period. ${ }^{40}$ This was particularly the case within the Conservative Party. A party that was culturally and emotionally intertwined with rural England, interwar Conservatives saw themselves as having a special historical connection to the English countryside. ${ }^{41}$ At a time when, as Clare Griffiths has persuasively argued, the Labour Party contested the Conservative's hold on the countryside, such an identity arguably became more important. ${ }^{42}$ As such, by engaging in questions related to the health of British agriculture, Perry was connected to debates that resonated beyond the farm gate.

The first of these debates was the long-standing "land question." Far from dying out in the Edwardian period, arguments over land ownership remained an issue for many Conservatives as long as Labour was committed to land nationalization. ${ }^{43}$ As part of its wider program, Labour argued that landlordism, like other forms of capitalist ownership, contributed not only to the poor state of industry but also maintained outdated social hierarchies. ${ }^{44}$ Equally controversial was the debate about what role the state should play in private agriculture. Following the collapse of farm prices in 1929, the National Government introduced tariffs on a range of food stuffs, including wheat, and created a number of agricultural marketing boards that restricted imports and controlled marketing, pricing, and even production. ${ }^{45}$ A form of compulsory cooperation, such boards were hailed by many reform-minded Conservatives, such as Walter Elliot, the Minister of Agriculture, as part of an alternative corporatist "new economic order" that would lift Britain

${ }^{40}$ Peter Mandler, "Against 'Englishness': English Culture and the Limits to Rural Nostalgia, 1850-1940," Transactions of the Royal Historical Society 7 (1997): 155-75.

${ }^{41}$ Berthezène, Training Minds, 169-85.

${ }^{42}$ Clare Griffiths, Labour and the Countryside (Oxford, 2007).

${ }^{43}$ F. M. L. Thompson, "Epilogue: The Strange Death of the English Land Question," in The Land Question in Britain, 1750-1950, ed. Paul Readman and Matthew Cragoe (Basingstoke, 2010), 257-70.

${ }^{44}$ Clare Griffiths, "Socialism and the Land Question: Public Ownership and Control in Labour Party Policy, 1918-1950," in Readman and Cragoe, eds., The Land Question in Britain, 237-56, at 242.

${ }_{45}$ Peter Self and Herbert J. Storing, The State and the Farmer: British Agricultural Policies and Politics (Berkeley, 1963), 88. 
out of the slump. ${ }^{46}$ Likewise, it was not just the ownership of land or the control of farming that were at stake, but the question of what kind of farming should occur. The interwar years witnessed the emergence of an organic farming movement that challenged the growing business and commercial focus of those like Perry. Instead, men like Rolf Gardiner and Viscount Lymington, who sat in an uneasy ideological space between Fascism and High Toryism, argued for a return to an older, less intensive form of cultivation based on soil preservation and the revival of indigenous folk traditions-all as part of a wider plan to recreate the nation's lost aristocratic leadership. ${ }^{47}$ Interacting with questions of ownership, government control, trade policy, and the moral character of the people, arguments about the health of agriculture and the rural community were not only a subject of political debate but also an active site of it. Perry's decision to undertake the Fordson experiment and broaden its social element was, therefore, a political act.

Given the political issues at stake, Perry and Ford were far from alone in undertaking an experiment in rural revival. The interwar years saw the creation of a host of innovative agricultural ventures designed to test the applicability of different political and economic philosophies; their proponents hoped they would transform the country as well as the countryside. From the late 1920s onward, rural England became a literal test bed: a place to work out ideology in practice and to advertise solutions to wider problems of the political, economic, and moral dilemmas that were plaguing Britain, and in some cases, the modern world. As a result, the Fordson experiment was political not just in its form and content but also in its competitive element-a point well recognized in press accounts that compared it to contemporaneous agricultural experiments. ${ }^{48}$

As a result of the desire to relieve unemployment and the collapse of land prices, from the late 1920s onwards the English countryside was bursting with schemes for rural regeneration. Prominent among these was the project run at Dartington Hall by Leonard and Dorothy Elmhirst. Embracing modern farming methods, arts and crafts, and international performers, Dartington was positioned as an attempt to resurrect the social and economic functions of the medieval manor and to become a model for a more planned rural economy. ${ }^{49}$ By contrast, Rolf Gardiner, a far-right advocate of rural revival, developed his Springhead Estate in Dorset as a small self-sufficient organic unit. His estate sprang from his belief in the importance of regional diversity and elite leadership, against what Gardiner believed to be the homogenizing and Americanizing tendencies of modern Britain and the demand for a more planned and rationalized society coming from those like the Elmhirsts. ${ }^{50}$

\footnotetext{
${ }^{46}$ Daniel Ritschel, "A Corporatist Economy in Britain? Capitalist Planning for Industrial Self-Government in the 1930s," English Historical Review 106, no. 418 (January 1991): 41-65, at 58.

${ }^{47}$ R. J. Moore-Colyer, "Rolf Gardiner, English Patriot and the Council for the Church and Countryside," Agricultural History Review 49, no. 2 (2001): 187-209; R. J. Moore-Colyer, "Back To Basics: Rolf Gardiner, H. J. Massingham and A Kinship in Husbandry," Rural History 12, no. 1 (October 2008): 85-108; Richard Moore-Colyer and Philip Conford, "A'Secret Society'? The Internal and External Relations of the Kinship in Husbandry, 1941-52," Rural History 15, no. 2 (October 2004): 189-206; Dan Stone, "The Far Right and the Back-to-the-Land Movement," in The Culture of Fascism: Visions of the Far Right in Britain, ed. Julie V. Gottlieb and Thomas P. Linehan (London, 2004), 182-98.

48 "Experiments in Land Settlement," Saturday Review (London), 16 November 1935.

49 Dennis Hardy, Utopian England: Community Experiments, 1900-1945 (London, 2000), 121.

${ }^{50}$ Moore-Colyer, "Back To Basics," 92.
} 
The competition of different ideological and political traditions was not only between those with different attitudes to planning. For example, philosopher J. W. Scott ran his own Homecroft Movement for the unemployed near Gloucester as part of an attempt to demonstrate the utility of the ideas of C. H. Douglas and the Social Credit movement, ${ }^{51}$ while at Langenhoe in Essex distributionist ideas and the philosophies of Hillaire Belloc and G. K. Chesterton informed a similar scheme. ${ }^{52}$ At times, religious motives drove schemes forward. The Catholic Land Federation, for example, operated a scheme in Market Bosworth in Leicestershire to relieve unemployment, ${ }^{53}$ while at Brynmawr in South Wales, the Quakers took the lead role in a scheme to aid out-of-work miners. ${ }^{54}$ Testing theories about leadership, political economy, and religion, interwar ventures in making new rural communities were of course part of a longer history of using the land as a site for rebuilding or reimagining society on both the Left and on the Right-from the Owenite communities of the 1810s to the dreams of peasant proprietorship advanced by Conservatives in the mid-nineteenth century. Yet, the differences between the Fordson Estate and other interwar agricultural ventures demonstrate not only the specificity of the era but the Conservative politics that were at the core of Perry's experiment.

In many ways the difference in the politics between the Fordson experiment and other schemes of rural generation are demonstrated in areas that, at first sight, do not appear political. To start with, there was none of the aesthetic medievalism that was on display at Dartington, with the Elmhirst's restoration of the great hall's hamerbeam roof and medieval courtyard. Instead, the Fordson experiment combined the latest commercial architecture-its estate office was described as looking like a "Hollywood villa"-with a contrasting domestic architecture that sought to harmonize the modern with the traditional. ${ }^{55}$ The housing that the estate began building in 1935, with ever-rising costs that infuriated Ford, was deliberately built in the Essex vernacular style, while also including modern amenities like electricity and a mainline sewage system. Nor was there an attempt to dictate or control the religious life on the estate, even though Perry supported Boreham's local Anglican Church and organizations, like the Industrial Welfare Society, that promoted "Christian feeling" in industry. This stood in stark contrast to activities at Market Bosworth with its Catholic theology, and also differed markedly from Henry Ford's own position-the automaker enforced strict temperance in his factories and expected his American agricultural estate's workers to attend services at the various chapels he built. ${ }^{56}$ Furthermore, Perry's relationship to planning, though it was more hostile to state involvement than the Elmhirst's, did not slip into denunciations of government activity in farming, as was the case with Gardiner. Rather, by creating a host of specialized "central" services to undertake marketing, bulk buying, and finance, Perry sought to balance the attention the state increasingly paid to

51 "Experiments in Land Settlement," 462-63.

${ }^{52}$ Hardy, Utopian England, 218.

53 "Experiments in Land Settlement," 462.

${ }^{54}$ William Temple and Pilgrim Trust, Men without Work: A Report Made to the Pilgrim Trust with an Introduction by the Archbishop of York and a Preface (Cambridge, 1938), 355.

55 James Wentworth Day, Farming Adventure: A Thousand Miles through England on a Horse (London, 1943), 88.

${ }^{56}$ Bryan, Beyond the Model T, 190. 
agriculture in the form of marketing boards, along with the administrative burdens he believed such boards created. ${ }^{57}$ As Perry stated, such a form of organization allowed the agriculture industry to enjoy government support while ensuring the individual farmer was not forced to "chew pencil ends and make returns when he really ought to be out on the land following the arbitrary dictates of nature." $" 58$

Most importantly, the Fordson Estate differed from other prominent experiments in rural regeneration by not positioning itself as an escape or alternative to modern commercial society. Rather, by integrating the modern with the traditional, it was hoped that the positive possibilities of commercialization would be more completely realized. This was illustrated at the Fordson Estate not only by what they cultivatedat Fordson, unlike at Dartington, those areas deemed unprofitable were ruthlessly closed-but also how they sold their produce. Marketing Fordson's vegetables as branded goods, the estate engaged in ingenious forms of advertising, such as selling cucumbers like cigars, with paper bands around their middle advertising their Fordson origin. ${ }^{59}$ Here, food was recognized for what it had become for Perry: a commodity to be bought and sold for profit (rather than, as for Lymington, as an end in itself). Also, in keeping with automotive marketing practice and the ideas behind marketing boards, the estate refused to work through what Ford held to be unproductive middlemen, instead selling the food directly to individual customers through stalls Spitalfield market and the Dagenham Plant. Here, this practice represented the twin temporal elements of conservative modernism: the belief that this was a more productive and efficient form of economic organization in an age of mass production, but also a means to restore the personal connection between producer and consumer that had been lost. The Fordson Estate, with its attempt to marry the modern and traditional, its support for a generalized but nonspecific Christianity, its desire for state support without bureaucracy, and its celebration of commercial industry, was therefore not just the a manifestation of the culture of interwar conservatism but an attempt to practice the conservative modernity that lay at its heart.

Conservative modernity, and its links to wider Conservative politics, can best be seen when Fordson is compared to other schemes for rural regeneration that were sponsored or undertaken by industrialists on both sides of the Atlantic, and which appear superficially similar. In Britain, the two most famous of these other industrialist-funded schemes were retailer John Lewis's scheme in partnership farming at Leckford in Hampshire, and the cement manufacturer Sir Malcolm Stewart's settlement for the unemployed at Potton in Bedfordshire. Indeed, the Potton Estate became the basis for the government's own small-holdings scheme run by the Land Settlement Association from 1934 onward. In both cases, the primary difference between these schemes and Fordson was not farming methods-Leckford embraced a similar focus on mechanization and the Land Settlement Association's scheme adopted a similar centralization of core services-but rather the relationship

\footnotetext{
57 "Second Meeting of the Workers of Fordson Estates, held at Boreham House, Boreham, Essex: Speech by Sir Percival Perry," 25 April 1936, Engineering Laboratory Office Records Subgroup, 1943-1944, Accession 285, Box 2681, 5, THF.

58 "Speech by Sir Percival Perry," 9 March 1935, Engineering Laboratory Office Records Subgroup, 1943-1944, Accession 285, Box 2681, 5, THF.

59 Perry, Ten Years' Romance, 17.
} 
with the local rural community. This went to the heart of Perry's desire to regenerate not only the countryside but also its rural citizens.

Fordson workers were encouraged to integrate themselves into the community, unlike at the Land Settlement Association's estates, where the desire to see each settler work his own individual plot often led to isolation. Leckford, too, sought to create its own community, but the Fordson Estate wanted to enmesh itself within that already existing at Boreham. The creation of a totalizing social environment-as was so often the case in company model villages such as Port Sunlight, Saltaire, or Bourneville-was not for Perry. At Fordson, no purpose-built social amenities were provided as they were at both Leckford and on Ford's US estates, where the automaker built schools, shops, hospitals, and kindergartens, and where he encouraged his employees to learn traditional crafts and dances. ${ }^{60}$ Similarly, the Fordson Estate worked through, rather than against, the existing paternal and spiritual structures of authority in Boreham village. To this end Perry made significant donations toward the restoration of the local church. ${ }^{61}$ Perry was also a prominent supporter of events to raise funds for the village hall, and he often opened up Boreham House to hold fêtes and other social occasions for villagers. ${ }^{62}$ Indeed, Perry shared the sentiment common to organizations like the rural communitycouncils - which were funded in part by the Carnegie UK Trust-that the development of village halls was necessary to maintain the rural community as a distinct alternative to urban society. ${ }^{63}$

Such support for existing local organizations and institutions was fundamental to the type of new rural citizen that Perry wanted to construct on the Fordson Estate. As Clarisse Berthezène has demonstrated, many Conservatives in the period imagined that citizenship flourished in the kind of organic society that Perry sought to recreate at Boreham. ${ }^{64}$ Rather than an understanding of citizenship that emphasized its communitarian dimension-and thus the necessity for economic equality to produce active citizens-the more individualistic Conservative version of citizenship focused on equality of service and sacrifice over rights. Its aim was to integrate the nation's citizens, of all classes, through civic equality and the socially ameliorative concept of shared duties. Such a version of citizenship would act as a counterpoise to socialist politics based on class tensions, as well as a bulwark against the growth of totalitarianism that, many believed, relied upon a passive electorate.

During the 1930s, Conservatives sought numerous ways in which to inculcate this form of citizenship with its emphasis on citizens' communal duties and participation through established parliamentary politics. For some, such as the Conservative historian Arthur Bryant, the answer was to promote a Tory school of history that emphasized "sound" and "traditional" views on the evolution of Britain's

\footnotetext{
${ }^{60}$ Christopher E. Wilson, “The Richmond Hill Experiment Henry Ford’s Social Engineering Project in Georgia, 1925-1951" (MA diss., Wayne State University, 2007); Ivan Willi Parker, "The Macon Experiment in Rural Education" (PhD diss., University of Michigan, 1946).

61 "Meeting of Directors," 15 October 1937, Fordson Estates Limited Records, Accession 2004.102, Box 1, THF.

62 "Boreham Village Hall Opened by Lord Perry," Chelmsford Chronicle, 27 May 1938.

${ }^{63}$ Jeremy Burchardt, "A New Rural Civilization': Village Halls, Community and Citizenship in the 1920s," in The English Countryside between the Wars: Regeneration or Decline?, ed. Paul Brassley, Jeremy Burchardt, and Lynne Thompson (Woodbridge, 2006), 26-35.

${ }^{64}$ Berthezène, Training Minds, 141-53.
} 
constitution. ${ }^{65}$ In a similar vein, Stanley Baldwin employed rhetoric that, alongside his wider educative efforts, celebrated Britain's "apolitical" associational life and the class harmony and public service that organizations, from the Women's Institute to the British Legion, embraced. ${ }^{66}$ Still others, notably Noel Skelton, the Conservative $\mathrm{MP}$ and intellectual, promoted the idea of a "property-owning democracy," as a means to engender civic responsibility and social maturity. ${ }^{67}$ Helping to support the organic and associational patterns of life of rural England was only part of Perry's plan; his primary focus was, by contrast, to promote this Conservative understanding of citizenship specifically through work.

In focusing on the workplace as a site for developing citizenship, Perry combined a belief in the paternalist duty to provide secure and stable employment with a faith that, by giving workers their share of profits, sympathy would grow up between employers and employed. Just as the Conservative MP Michael Seymour complained in 1930 that "the manufacturer or the employer in the industrial area must not keep his sense of social service for his suburban home," so Perry hoped that his profit-sharing scheme would ensure the creation of more "responsible" landlords as well as more "responsible" workers. ${ }^{68}$ If Conservatives like Baldwin, Bryant, and Skelton all sought to promote a Conservative vision of citizenship that they hoped would flow from the political realm to the industrial, Perry reversed this direction. For him—as for organizations like the Industrial Welfare Society, who sought to persuade employers to provide workplace social services, and the Economic League, who organized tens of thousands of factory "study circles" on the principles of capitalism-the hope was that class collaboration and cooperation in the workplace would be transformed into support for wider "constitutional" politics outside the factory gate. ${ }^{69}$

Perry's decision to widen the remit of the Fordson experiment from an attempt to test farming techniques to a model of wider rural revival was thus deeply politicalboth in terms of Fordson's competition with (and distinction from) other schemes for rural regeneration and in Perry's desire to create a particularly Conservative type of rural citizen. Focusing on the construction of citizenship via work, the central part of Perry's plans for the organization of the Estate was to adopt copartnership, a well-known vehicle for industrial collaboration, and rework it to meet the specific problems he identified with the English countryside.

\section{COPARTNERSHIP FOR THE COUNTRYSIDE}

At the heart of copartnership is a commitment to sharing a firm's profits with workers after provision has been made for rewarding capital. Though there had been experiments in copartnership in the coal trade during the 1860s, support for

${ }^{65}$ Ibid., chap. 6.

${ }^{66}$ On the role played by such organizations in interwar political culture see also Helen McCarthy, "Parties, Voluntary Associations, and Democratic Politics in Interwar Britain," Historical Journal 50, no. 4 (December 2007): 891-912.

${ }^{67}$ David Torrance, Noel Skelton and the Property-Owning Democracy (London, 2010).

${ }^{68}$ As quoted in Berthezène, Training Minds, 144.

${ }^{69}$ Industrial Welfare Society, Welfare in Industry (London, 1942); Arthur Mclvor, "A Crusade for Capitalism': The Economic League, 1919-39," Contemporary History 23, no. 4 (October 1988): 631-55. 
this form of economic organization among employers had fluctuated with levels of industrial conflict, peaking in the late $1920 \mathrm{~s}^{70}$ Opposed by many in the labor movement who saw it (often rightly) as an attempt to weaken trade unionism, the concept of copartnership was, in the 1920s, backed by important elements within the Conservative Party. These included the former prime minister Arthur Balfour-whom Perry described as a close friend-Harold Macmillan, and Lord Hugh Cecil. ${ }^{71}$ In fact, in 1927, Cecil attempted to push in cabinet his idea that the state provide tax breaks to firms engaged in the process. ${ }^{72}$ Copartnership was also strongly supported by Stanley Baldwin. Yet like his support for the idea of relocating factories to the countryside, Baldwin's rhetoric-which included invoking the spirit of partnership at his father's iron works- did not translate into legislative action. ${ }^{73}$ Instead, the Conservatives in office during the 1930s focused on a voluntary approach to industrial relations, suggesting that, beyond exhortation, there was little that the state could do to ensure that workers and employers cooperated. ${ }^{74}$ Nor, as John Ramsden has argued, were such proposals for profit sharing always supported by the party's working-class activists, who argued that they were merely palliatives and not an alternative to increasing the overall health of industry through tariffs. ${ }^{75}$ As such, from the late 1920s onward, copartnership as a policy, rather than as rhetoric, was more usually associated with the Liberal Party.

Copartnership had long been associated with a number of Liberal-supporting employers - such as the chocolate manufacturer Seebohm Rowntree, the chemical industrialist Alfred Mond, and the soap magnate William Lever. It was also promoted in the 1928 Liberal "yellow book," Britain's Industrial Future and David Lloyd George's 1929 We Can Conquer Unemployment. ${ }^{76}$ As with many of the other advocates of copartnership who backed such schemes after 1945, in these Liberal texts profit sharing and copartnership were explained as a way to ensure workers did not consider themselves to be just tools in industry, but active partners in its success who were, therefore, more willing to engage in processes to increase efficiency. ${ }^{77}$ Perry agreed with these aims. Indeed, he was a public supporter of the Profit-Sharing and Co-Partnership Association, one of a number of propaganda organizations that promoted the concept. ${ }^{78}$ Yet, the way that copartnership was implemented on the Fordson Estate reveals Perry's wider motives.

\footnotetext{
${ }^{70}$ Edward Bristow, "Profit-Sharing, Socialism, and Labour Unrest," in Essays in Anti-Labour History: Responses to the Rise of Labour in Britain, ed. Kenneth D. Brown (London, 1974), 262-89.

${ }^{71}$ Percival Perry to Edsel Ford, 7 August 1931, Edsel B. Ford Office Papers 1903-1945, Accession 6, Box 282, Folder "Personal File, Manchester," THF.

72 Bristow, "Profit-Sharing," 287.

${ }^{73}$ Ramsden, Age of Balfour and Baldwin, 207.

${ }^{74}$ Peter Dorey, British Conservatism and Trade Unionism, 1945-1964 (Farnham, 2009), 14.

75 Ibid., 254.

${ }^{76}$ Liberal Industrial Enquiry, Britain's Industrial Future (London, 1928), 198-203; David Lloyd George and Liberal Party, We Can Conquer Unemployment (London, 1929), 7.

77 See also Alfred Emmott, Nationalization of Industries: A Criticism (London, 1920), 20; Liberal Industrial Enquiry, Britain's Industrial Future, 198-203; "Sir Basil Peto: An Appreciation," Times (London), 14 February 1945; Conservative Research Department, "Industrial Relations and Co-Partnership," Notes on Current Politics, no. 15 (24 October 1955): 13-15; J. Ward Daw, "The Case for Co-Partnership," Peoples Guardian (London), 27 August 1960.

${ }^{78}$ Robert Hyde, Industry Was My Parish: Being the Autobiography of Robert R. Hyde (London, 1968), 103.
} 
The model of copartnership created by Perry for the Fordson Estate was complex. Following Ford's request that the estate be run on cooperative lines, the estate was divided into three separate cooperative societies. Membership of the societies was open to all who had worked on the estate for at least two hundred days. Societies were then offered a thousand-year lease and paid Ford and Perry a charge of 4 percent on the capital used to improve the estate. Alongside wages, calculated to be 25 percent above the county minimum, at the end of each year a bonus was paid. The amount a worker received as a bonus corresponded directly to the profit made by each society, divided in accordance with the distribution of wages.

Behind this form of organization stood Perry's wider views on political economy, specifically his belief that capital was no more than the accumulation of unexpended rewards of past labor. As such, the aim of the scheme, Perry argued, was to remunerate capital and present labor appropriately. It was, as Perry wrote in 1945, a "crude attempt to deal with the 'rentier' problem and prevent the growth and building up of unearned increments and absentee vested interests." 79 Perry sought to remove the injustice of those who did most to increase the land's value, namely the agricultural worker, receiving the slimmest financial reward.

In determining the influence of liberalism on the interwar Conservative Party historians like Julia Stapleton and David Thackeray have highlighted the extent to which Conservatives and the Conservative Party drew on rhetoric of "Englishness" and forms of campaigning that had liberal roots. ${ }^{80}$ By contrast, at Fordson, Perry's implementation of copartnership drew heavily not only on liberal ideas but on specific policies adopted by the Liberal Party. Indeed, Perry's form of organization was a direct attempt to blend plans for industrial copartnership with interwar Liberal land policies; these were influenced by the American political economist Henry George, who argued that the concentration of land was the underlying cause of poverty. Early incarnations of these land policies had taken the form of support for Land Value Taxation, preparations for which were controversially included in Lloyd George's 1909 "People's Budget." By the early 1930s, however, Liberal policies on agricultural land had evolved. While continuing to embrace some Georgist elements, the policy of "cultivating tenure" had begun to take shape. Developed from 1923 under the auspices of Lloyd George's rural land committee, and announced in the Liberal Party's 1925 "green book," titled The Land and the Nation, the new scheme involved the state's purchasing agricultural land and leasing it back to farmers at a fixed rate- one that was net of the costs of improving the land and that thus excluded the land's "monopoly value." 81 In order to assure that the land was worked properly, county agricultural authorities would supervise cultivation and arrange for the creation of new allotments, farms, and small holdings. The aims of this scheme were to ensure that tenants had security of tenure, that there was sufficient capital to invest in increasing the land's productive ability, that

${ }^{79}$ Perry, Ten Years' Romance, 4.

${ }^{80}$ Julia Stapleton, "Resisting the Centre at the Extremes: 'English' Liberalism in the Political Thought of Interwar Britain," British Journal of Politics and International Relations 1, no. 3 (October 1999): 270-92; Thackeray, Conservatism for the Democratic Age, 19-30.

${ }^{81}$ Liberal Land Committee, The Land and the Nation: Rural Report of the Liberal Land Committee, 1923-1925 (London, 1925). 
land was cultivated properly, and that any increase in its value went to the community. ${ }^{82}$

The policy of "cultivating tenure" had been attacked outside and inside the Liberal Party as tantamount to nationalization. ${ }^{83}$ Perry's alternative to "cultivating tenure" as represented in the organization of the Fordson Estate was a Conservative attempt designed to meet Liberal and Georgist ends without state involvement. The thousandyear lease gave tenants security of tenure. The abolition of rent in favor of a 4 percent charge on capital provided an incentive to landowners to invest as they would in other industrial undertakings. Crucially, however, this investment did not provide any "unearned" reward for the increase in land values while profit sharing encouraged workers to maintain high levels of production. Equally important, it ensured that control rested in the hands of those who Perry believed were best able to exercise it-men with management experience, rather than civil servants. At Fordson, Perry and his fellow directors retained full control of the cooperative societies and decided who could, or could not, become or remain a member. Moreover, all of these changes designed to spur efficiency were to be achieved without any increase in government spending needed to compensate existing landlords.

Examining the names of those involved with the estate confirms the links between the Fordson experiment and the Liberal land campaign. The Fordson Estate's board of directors included John Thomas Davies, Lloyd George's private secretary between 1917 and 1922, and Christopher Addison, a key advisor to Lloyd George on land taxation. ${ }^{84}$ Addison, who had joined Labour in 1923, hailed the Fordson experiment as a preferable alternative to Labour's nationalization plans in his 1939 study A Policy for British Agriculture. ${ }^{85}$ Lloyd George himself also wrote to Perry to congratulate him on the experiment. ${ }^{86}$ Speaking in a 1954 interview, Perry explained the link between the Fordson Estate, the Liberal land campaign, and Georgist ideas. He stated that "Henry George has got it absolutely right in a brand new country where you didn't have vested interests to keep up," but that the Fordson experiment was a more appropriate model for a country like Britain. ${ }^{87}$ The virtue of this scheme being that co-operators would work the land and own the profit from their endeavors while paternalistic landlords would be rewarded for their responsible attempts to improve its productivity. As such, though the ideas behind the scheme had a Liberal origin, the aim was to realize the Conservative ideals of intermeshed social relationships, in this case between workers and owners, and an equality of sacrifice with only those who played a part in increasing the health and wealth of the land as a whole receiving financial rewards.

While increasing efficiency and removing the problem of the "rentier" from agriculture was important for Perry, it was not the only advantage of the scheme. As Perry

\footnotetext{
${ }^{82}$ Michael Dawson, "The Liberal Land Policy, 1924-1929: Electoral Strategy and Internal Division," Twentieth Century British History 2, no. 3 (January 1991): 272-90.

${ }^{83}$ J. Graham Jones, "Sir Alfred Mond, Carmarthenshire and the 'Green Book," Welsh History Review 19, no. 3 (June 1999): 487-516.

84 "Meeting of the Fordson Estate Directors," 9 June 1938, Fordson Estates Limited Records, Accession 2004.102, Box 1, THF; "Meeting of Directors," 30 July 1936, Fordson Estates Limited Records, Accession 2004.102, Box 1, THF.

${ }^{85}$ Christopher Addison, A Policy for British Agriculture (London, 1939), 254-59.

86 "Speech by Sir Percival Perry," 25 April 1936, 1.

${ }^{87}$ Nevins and Hill, "Interview with Lord Perry," 50.
} 
explained in one of the numerous speeches he gave to Fordson employees, the project was designed to improve workers' moral health and capacity for productive citizenship. First, Perry believed it would not only bring more men onto the land but would allow them to "work in the open air in a healthy occupation full of interest and variety; they have an opportunity to develop an independence of character far away from the dreary monotony and drab surroundings of shops and factories." 88 Second, high wages and the shared profits offered by the estate enabled workers to, "realise their work was something valuable," and employees were therefore not paid, "under the cloak of philanthropy [beneath which] workers have been underpaid for generations." 89 In contrast to the initiative-sapping impact of philanthropy, Perry argued that high wages, like those paid in Ford factories, were the result of valid commercial decisions and increased productivity, by generating a sense of self-respect and the opportunity to engage in constructive leisure outside of work. ${ }^{90}$ Finally, and most importantly, the scheme ensured that individual workers did not just benefit from the capitalist economy but also took part in it. As Perry proudly proclaimed in 1936, "as a result of our experiments over the last two years every one of our Co-operative workers has become a capitalist. It is most desirable they understand this." ${ }^{\prime 1}$ For Perry, economic and political citizenship were inherently interlinked.

Here, participation in the capitalist economy was not simply invested in generating "enterprise consciousness"- the replacement of class with employer identity so men and women would think of themselves as Ford workers rather than just as workers alone. Rather, copartnership, like Conservative support for associational politics, was seen as a way of building citizenship, in this case a specific form of industrial citizenship. Participating in profit-sharing schemes gave workers a practical education in the vicissitudes of capitalist life and the reasons behind decisions taken by employers. Perry and his manager on the estate spent considerable time and effort explaining the reasons behind new cropping and marketing plans and why certain schemes on the estate, such as the plan to open a fruit bottling plant, had to be rejected. Likewise they offered a clear example and space for different class interests to come together.

Most importantly, though, copartnership provided an opportunity for the cultivation of a specifically Conservative understanding of individualism. In common with the view of individualism shared by some of the more "classical liberal" proponents of copartnership — such as the Liberal MPs Henry Vivian and Harold Cox, and the publisher Ernest Benn-Perry argued that real individualism came from the voluntary sublimation of immediate selfish demands in favor of acting in the interest of the community. ${ }^{92}$ Cox, Vivian, and Benn nonetheless presented sublimation to the community in terms of "self-help"-providing for oneself through individual effort rather than relying on the state. ${ }^{93}$ Perry, by contrast, explicitly linked the development of individualism to participation in the capitalist economy. To Perry, who believed

88 "Speech by Sir Percival Perry," 25 April 1936, 11.

89 "Farm Profits for Employees," Chelmsford Chronicle, 15 March 1935.

${ }^{90}$ For a similar distrust of philanthropy among paternalist employers, see also, Charles Dellheim, "Utopia Ltd: Bournville and Port Sunlight," in Cities, Class and Communication: Essays in Honour of Asa Briggs, ed. Derek Fraser (London, 1990), 44-57, at 45.

91 "Speech by Sir Percival Perry," 25 April 1936, 12 (italics in original).

${ }_{92}$ Ernest J. P. Benn, This Soft Age, with the Optimistic Theory of the 30/50 Man (London, 1933), 14-15.

93 Ibid. 
that the interests of the community were best served by profitable farming, following the dictates of the capitalist economy thus became itself a form of individual development and a means to generate personal responsibility.

With his commitment to modernization of farming and managerial techniques, the abolition of the "absentee owner," and the development of an independent and responsible workforce, Perry made clear that the experiment was meant as a template for other agricultural endeavors across the country. ${ }^{94}$ Pointing to the availability of other estates in a similar position to Boreham, he suggested that both the government and other industrialists would only be too pleased to receive the 4 percent return on their investment that the Fordson experiment generated for Henry Ford. ${ }^{95}$ Yet, it was not just agriculture and the rural community that, according to Perry, could benefit from following the Fordson Estate's example. Rather, as Perry stated in 1936, the experiment served as a wider example of how "to achieve a state of affairs in national life which, if attained, should prove to be a serious contribution to solving social and political problems which are now the cause of so much economic chaos and political unrest." 96 Fordson embodied principles that Perry believed were right for the country as well the countryside, yet their implementation was frequently socially problematic.

\section{THE FORDSON ESTATE: OPERATION AND RECEPTION}

Accurately gauging the economic and agricultural success of the Fordson experiment is difficult due to its shifting size and the destruction of its financial records. Nonetheless, in the decade between 1935 and 1945, when the form of organization described above was fully in operation and financial records existed, the Fordson Estate appears to have performed well. In terms of providing more land-based jobs, the estate went from employing 2.68 men per one hundred acres to more than twice that number only two and a half years later. ${ }^{97}$ Between 1935 and 1945, these ratios grew further, if unevenly. By 1945, Perry was able to claim that at any one point in time during the previous decade, on average two hundred men had been employed across the estate. ${ }^{98}$ Boreham Estate Co-Operative (one of the three societies that made up the Fordson experiment), for example, went from employing six men and one boy in 1931 to a workforce of fourteen permanent employees in 1935. 99

Though the Fordson experiment succeeded in increasing the land's productive ability in cash terms-sometimes dramatically, as in the case of one farm which went from generating revenue of $£ 2,000$ a year in 1931 to over $£ 30,000$ in 1935-the effect of the experiment on the overall profitability of the estate was more mixed. ${ }^{100}$ Higher wages and more expensive inputs meant that the individual

${ }^{94}$ Among those attending the 1936 AGM were, for example, the lord lieutenant of Essex, the high commissioner for the Irish Free State, and the permanent secretary to the Ministry of Agriculture.

95 "Speech by Sir Percival Perry," 25 April 1936, 3; "Lord Perry Hints to Government," Western Daily Press (Bristol), 22 August 1938.

96 "Speech by Sir Percival Perry" 25 April 1935, 12.

${ }_{97}$ Perry, Ten Years' Romance, 11.

98 Ibid., 18.

99 Agricultural Correspondent, "Mechanization on the Land," Times (London), 30 September 1935.

100 Ibid. 
societies did occasionally suffer losses, particularly in 1937 and 1939, when a series of severe frosts caused losses of $£ 1,152$ and $£ 253$ respectively. ${ }^{101}$ By contrast, the period between 1940 and 1945 were boom years. Wartime guaranteed prices meant that the estate as a whole made over $£ 20,000$ in 1945 alone- a figure almost ten times greater than the highest profit made prior to the outbreak of war. ${ }^{102}$ Such financial success allowed Perry to claim in 1945 that over the course of the preceding decade, 181 men had shared in total bonuses of over $£ 147,000,{ }^{103}$ with the average bonus being 45 percent of normal wages. ${ }^{104}$ Nonetheless, even in the less-favorable years of the mid-1930s, high bonuses were sometimes paid, with one worker receiving a bonus of $£ 148$ in 1935 , and even the youngest boy taking home an additional $£ 5.105$

These accomplishments triggered considerable publicity. In 1935, after learning of the large bonuses paid to workers and the estate's success in mechanized farming, the Times recommended Perry and Ford's methods be more widely adopted in schemes of land settlement and spoke of it as allowing men "a chance of winning economic independence." 106 The Irish Times also suggested their system be adopted in the Free State as an alternative to the government's plans for small holdings, suggesting that it would "ensure the rapid development of an industry that has been too long neglected."107 In the same vein, the Saturday Review argued that the Fordson Estate was an example of private enterprise "striding along" in reviving agriculture in comparison to the aloof attitude taken by the Government. ${ }^{108}$ Only the English Review, mouthpiece of the English Rural Right, was critical. The writer Ian MacPherson was worried that the example of Fordson might attract those to the land who had less respect for the traditional life of the English countryside. He nonetheless claimed that Fordson-as an example of what capital "judiciously applied can do to increase the productivity of these islands"-was in itself not without merit. ${ }^{109}$

Despite MacPherson's hesitation, the estate's economic success and the breadth of coverage led the Ministry of Agriculture to take notice of the scheme in 1935. The ministry, in fact, received a direct request from the prime minister's office to examine Fordson's operation. ${ }^{110}$ The results of these investigations were not favorable to Perry. The ministry's officials critiqued the estate for undercutting the competition by growing crops, like brussels sprouts, which were already produced in Britain. The likely effect of any wide-scale expansion of the Fordson method would be, as one official report in 1935 declared, "to throw out of action thousands of smallholders and market gardeners already trying to get a living off the land."111

101 "Meeting of Directors," 15 April 1937, Fordson Estates Limited Records, Accession 2004.102, Box 1, THF; "Meeting of Directors," 27 February 1939, Fordson Estates Limited Records, Accession 2004.102, Box 1, THF.

102 "Meeting of Directors," 2 March 1945, Fordson Estates Limited Records, Accession 2004.102, Box 1, THF.

${ }^{103}$ Perry, Ten Years' Romance, 8.

104 Ibid., 17.

105 "A Novel Experiment," Cornishman (Penzance), 14 March 1935.

106 Agricultural Correspondent, "Mechanization."

107 "Mechanised Farming Creates Employment," Irish Times (Dublin), 5 November 1936.

108 "Experiments in Land Settlement."

109 Ian MacPherson, "The Machine on the Farm," English Review 63, no. 6 (December 1936): 607-12.

110 TNA, E. M. Watson CBE to D. B. Toye, 11 April 1935, MAF 48/284.

111 Hoare, "Fordson Estates." 
Likewise, the ministry determined that the estate's success had less to do with mechanization and more the fact that it was exploiting the existing good quality of the soil by ploughing up what had been virgin parkland. ${ }^{112}$

Less clear in these reports is the extent to which Perry had achieved the "individualism" he had sought to cultivate on the estate. Though the numbers applying to work at Fordson suggest its attractions-there were five applicants for every jobgauging worker response to the scheme is difficult. ${ }^{113}$ No records survive relating to attempts at unionization on the estate, though it likely would have been met with strong resistance. In fact, for all Perry's claims to have "settled" men on the land and provided "security of tenure," workers' contracts lasted only for a year, and men were frequently turned out if deemed unsatisfactory. ${ }^{114}$

What is clear, though, is that Perry was disappointed by the actions of Fordson workers. In a discussion between one Ministry of Agriculture inspector and the estate's manager, George Jones, the terminology used to describe workers reflected the classed way in which they were understood. Jones described how the best "material" were young lads, "material that can be developed on the desired lines" rather than older men with "set ideas" and "less flexible temperaments." 115 Nor were these young men seen to be reliable enough for positions of authority-Jones argued that "the material available in Essex" was "worthless" for jobs such as foreman, and instead recruited from his native Worcestershire in a practice that revealed the way identities of class and region remained intertwined. ${ }^{16}$ Moreover, even those who did survive for a year on the estate, and thus became full "co-operators," proved paradoxically problematic as a result of the estate's success. Perry recorded in 1945 that estate employees often received bonuses many times their monthly wages and as a result, "many improvident workers took their surplus earning $[\mathrm{s}]$ and spent them unwisely." 117 In response to this, the estate first established a savings stall at the annual ceremonial distribution of bonuses, which was then followed by a voluntary savings scheme, and finally, after the failure of both of these to encourage workers to willingly save, the estate compulsorily saved 30 percent of workers bonuses on their behalf. ${ }^{118}$

The relationship between the estate and Boreham village, the supposed heart of Perry's revived organic community, is easier to determine. The estate's imposition of rationalistic, universal understandings of legality over particular local customs and practices was frequently an issue. For example, overriding centuries-old tradition, villagers were prosecuted for gleaning the fields for unharvested produce. ${ }^{119}$ Similarly, an estate worker was jailed for what he believed to be the normal practice of using excess estate supplies to grow produce on his own land. ${ }^{120}$ By contrast, the community accused Ford and Perry of robbery when they sought to move a historic lodge once owned by Anne Boleyn to Ford's model village outside Detroit. Ford

112 TNA, H. V. Taylor, [untitled report], 14 May 1935, 1, MAF 48/284.

113 TNA, L. D. Gammans, "The Land Settlement Association: Circular No. 12: Fordson Estates," 21

March 1935, 1, MAF 48/284.

114 TNA, Taylor, [untitled report], 1.

115 Hoare, "Fordson Estates," 5.

116 Ibid.

117 Perry, Ten Years' Romance, 8.

118 "Farm Profits for Employees."

119 “Gleaners' Fined for Taking Peas," Essex Newsman (Chelmsford), 31 July 1943

120 "Boreham Men Are Accused," Essex Newsman (Chelmsford), 23 October 1943 
backed off only when the Campaign for the Protection of Rural England, the key preservationist organization of the period, mounted a public campaign against him. ${ }^{121}$ Even greater conflict would occur over the laborers working at Fordson and the growing number of Irish seasonal workers employed. Described by Perry as, "frequently haphazard, irregular, irresponsible, and socially undesirable," so-called casuals were a vital part of the estate's economics, often making up more than 50 percent of the workforce. ${ }^{122}$ Such men were not only excluded from the copartnership scheme but also from the estate's housing, and therefore were often found sleeping in ditches and haystacks. ${ }^{123}$ This situation occasionally had tragic consequences, such as when, in 1933, the body of a laborer was found amidst the smoldering remains of a burnt-out haystack. ${ }^{124}$ The parish council protested about this lack of accommodation and the presence of "undesirable labor employed by Fordson Estates that was impossible to control."125 Indeed, after having complained to the local newspaper that the estate failed to employ out-ofwork men from the village, one Boreham resident stated, "in other years Boreham has been peaceful, but now it is absolutely disgusting."126

Perry's and Ford's dream of applying methods of self-consciously modern industry to maintain traditional rural life thus contained numerous paradoxes. First, there was the conflict between the desire for profitability and the effect this had on the wider rural economy. Second, the dream of revitalizing traditional village life clashed with the imposition of an alien workforce and new legal practices. Finally, and most especially, the hope of developing individual responsibility by turning workers into capitalists was contradicted by the dismay with workers who, like their employers, might do what they wished with their newfound wealth. The last of these issues engaged Perry and the estate in a wider dispute among Conservatives committed to reducing unemployment by moving men to the land.

Having heard of the Fordson Estate's successes, Perry was visited by L. D. Gammans, chief executive of the English Land Settlement Association. A military officer and colonial civil servant, Gammans had toured Canada and India in 1930, hoping to discover a means to restore the prosperity of agriculture. He returned committed to the ideals of the Land Settlement Association, an organization fostering the positive effects of self-supervised work on character development. Visiting the Fordson Estate in 1935, he was dismayed by what he saw. While Perry claimed, in common with Ford, that mechanized copartnership farming removed the drudgery of small holding and provided high wages and a share of the profits, Gammans saw something quite different: a regime where absolute power was vested in the hands of Perry. ${ }^{127}$ For Gammans, Fordson was not a model for the future of British farming, let alone a solution to unemployment; it was "an experiment in co-partnership syndicated farming conducted under Fascist auspices."128

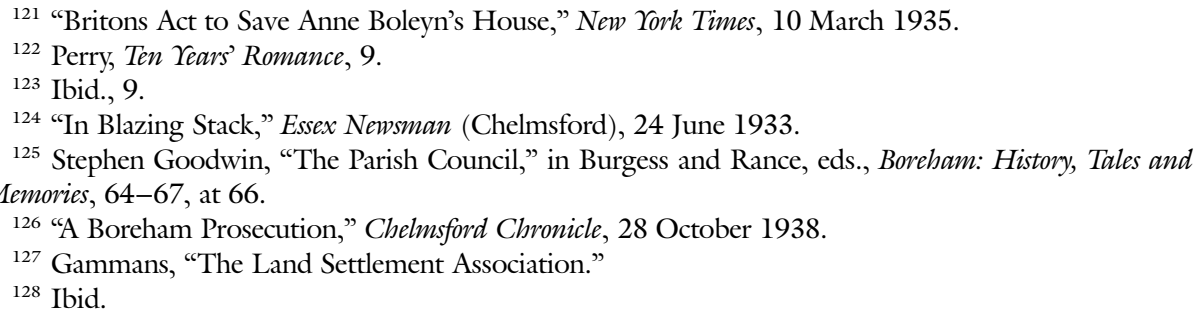


The strength of Gammans's language speaks to the fact that this was a wider, more profound ideological dispute than a conflict over farming methods. In one respect the debate between Gammans and Perry reflected a divide between Conservatives, like that between advocates of copartnership, about how best to cultivate the kind of responsible individualism they wished to see. On one side stood Perry, and indeed a number of other industrial paternalists, who saw individualism made possible by collective participation in the capitalist economy, the high wages, and a variety of activities that modern industry would bring. This would, they hoped, provide workers with the resources they needed to develop their own character. On the other side stood Gammans, and those like Noel Skelton and other Conservatives committed to wider property ownership, who saw individualism as stemming from the independence and security that property brought. Yet this debate was also about the relationship between freedom and paternalism-argued between those who saw independence as possible only within structures of paternalistic authority and those who saw those very structures as a negation of liberty. Indeed, as Jon Lawrence has shown, such debates in many ways went beyond the Conservative Party and characterized Britain's own "path to modernity."129

After the Second World War, arguably, the suggestion that property was the key to freedom came to predominance within the Conservative Party, with its emphasis on the "property owning democracy" in the 1950s and popular shareholding in the 1980s. Indeed, Gammans, who by 1942 had become a Conservative MP, played a leading role in this by becoming the principal postwar advocate of council tenants "right to buy." 130 During the interwar period, however, both approaches continued to work alongside one another in the context of the need to develop a specifically conservative form of citizenship at a time when Conservatives feared the development of both the extreme Left and Right. As such, when a government enquiry was set up in 1939 to investigate the future of land settlement schemes across England and Wales, it supported the Welsh Land Settlement Society, which had modelled their farming and copartnership arrangements specifically on the Fordson Estate. This Welsh society was assessed by the enquiry to be both more economical and preferred by workers themselves. ${ }^{131}$ In short, the enquiry supported the type of organization embodied in the Fordson experiment.

\section{CONCLUSION}

This 1939 declaration in favor of Perry's version of farming and land settlement would prove to be the high point for the Fordson Estate. Though the estate recorded its highest profits during the Second World War, these were largely due to agricultural prices guaranteed by the government - a form of direct state intervention in the economy to which the Fordson experiment had been set up to act as an alternative.

\footnotetext{
129 Jon Lawrence, "Paternalism, Class, and the British Path to Modernity," in The Peculiarities of Liberal Modernity in Imperial Britain, ed. Simon Gunn and James Vernon (London, 2011), 147-64.

${ }^{130}$ Aled Davies, "Right to Buy': The Development of a Conservative Housing Policy, 1945-1980," Contemporary British History 27, no. 4 (December 2013): 421-44, at 426-27.

${ }^{131}$ Committee of Enquiry into Land Settlement, Report of the Committee of Enquiry into Land Settlement (London, 1939), 110-11.
} 
The war also cut into the estate both literally and metaphorically. Large areas of land were given over to the construction of an American airbase in 1943, just as the Essex War Agricultural Committee challenged the control that Perry exercised over the estate. Even Perry and Ford's gendered understanding of farming came under attack as a result of the war, as members of the Women's Land Army were based on the estate in 1940. ${ }^{132}$ Yet, the Second World War did more than simply disrupt the life of the estate; it also transformed the political context in which it operated. The title of Perry's 1945 book on the experiment, Ten Years' Romance, reflects not just the romance of his idealized rural community, but also the nostalgia for a lost political moment when it seemed possible that the principles of enlightened ownership, co-partnership, and economic modernization could be harmonized and adopted across the country.

The estate had been purchased and developed in the early 1930s at a time of Conservative electoral hegemony. It represented an attempt to do outside Conservative politics what was believed to be impossible within a National Government committed to holding its disparate political elements together. Fordson was not an alternative to Conservative Party policies or the culture of conservative modernity; it embraced them. After 1940, and especially after 1945, both Perry's strategy and the wider type of Conservative politics it represented seemed outdated. Perry's dream of creating an economic structure that transcended the imagined poles of laissez-faire and state ownership were incompatible with a situation where the economy had already become planned and controlled, and where significant industries had already been nationalized. His hope of engendering greater cooperation between employers and employees was similarly outmoded in a period when trade unions had come to be seen-even among the most intransigent employers like Perry - as the legitimate representatives of justified sectional interests. ${ }^{133}$ Too piecemeal and long term in its aims, the Fordson experiment also appeared incompatible with a wartime moment when, as Bill Schwarz has argued, a collapse of an entire Conservative culture had occurred and where "the very categories of democracy, citizenship and welfare" had been transformed, "leaving Conservatism broken and incoherent." 134

It was within this changed political context that Perry founded the Conservative ginger group Aims of Industry in 1942 in order to halt what he saw as the ever expanding scope of bureaucracy, which, he declared, was "the antithesis and negation of all which we think we are fighting and hold most dear." 135 Perry saw this bureaucracy as potentially totalitarian long before Churchill uttered his infamous remarks during the 1945 general election about the potential need for a gestapo under a Labour government. ${ }^{136}$ Though Aims of Industry initially put forward a political program that mixed this more assertive antisocialism and antistatism with the politics of the Fordson experiment writ large-including statutory economic rationalization,

${ }^{132}$ Lord Perry to Edsel Ford, 9 January 1940, Edsel B. Ford Office Papers 1903-1945, Accession 6, Box 248, THF

${ }^{133}$ David, Ford at Dagenham, 93.

${ }^{134}$ Bill Schwarz, "The Tide of History: The Reconstruction of Conservatism, 1945-1951," in The Attlee Years, ed. Nick Tiratsoo (London, 1991), 147-66, at 155.

135 Percival L. D. Perry, Industry in Reconstruction (London, 1943), 5.

${ }^{136}$ Kowol, "The Lost World of British Conservatism," 161-72. 
minimum wages, and copartnership—by 1947 Aims of Industry and Perry's personal politics had slipped into simple negative denunciations of growing state socialism. ${ }^{137}$ Aims of Industry would, in fact, later be converted into an influential pressure group that, in working with a variety of free-market think tanks in the 1970s, campaigned against the kind of planned industrial rationalization and coordination its founder had once supported.

A similar ideological transformation occurred on the Fordson Estate itself. Robbed of its political raison d'être after the Second World War, the estate also lost its principal funder with the death of Henry Ford in 1947. Perry and a group of investors used this opportunity to purchase the entire estate. Though renamed Co-Partnership Farms, it was no longer held up as a model for the future of British agriculture, let alone British politics. The commitment to copartnership (except in name) was watered down and the Liberal and Georgist ideas that underpinned this particular implementation of copartnership were abandoned. Following Perry's death in 1956, the estate was eventually sold to the pension fund-financed Fountain Farming Group-precisely the kind of absentee owners that Perry had once actively sought to exclude. Even Boreham House is now no longer connected to Ford, Perry, or even to agriculture. Today, like so many other country houses, it serves as an event venue, used for weddings and corporate functions.

Yet, if the Fordson Estate was not the success its creators dreamed it would be, this should not detract from the analytical use that comes from studying its origins and development. In particular, the history of the Fordson Estate allows a more detailed and specific examination of the idea of conservative modernism. While, as a cultural and literary phenomenon, conservative modernism was a reaction to the traumas of the First World War, the story of Fordson reveals the extent to which it was also, for some Conservatives, a conscious and practiced political project. It was a way of thinking and acting that was driven by the desire to engage with other political actors and ideologies that contested the direction that Britain's modernity would take, from the dreams of moving forward to a rationalized and planned society to the wish to return to an imagined era of Victorian individualism. In this case, Fordson was an alternative to the host of other plans for rural land settlement that emanated from across the political spectrum and promised to use land as a test bed for a wider, radical remaking of society. Likewise, this was a conservatism that, in looking backward as well as forward, drew frequently not just on Conservative ideas of the past but, as in Perry's enthusiasm for the ideas of Henry George, Liberal ones from the present. Equally, the personal (or perhaps the personnel) politics of building Conservative citizens was one which went to the very heart of the Fordson experiment, with Perry and Ford's desire to transform not only the land but the moral character of those who worked on it.

Here, the Fordson experiment also helps illuminate the multiple and contested ways in which Conservatives sought to create independent, self-reliant citizens. It highlights the divisions between those who saw "responsible" citizenship beginning in the industrial rather than political arena. Likewise it emphasizes the difference between those who, like Perry, argued paternalism was necessary for workers to win their independence against others, like Gammans, who believed that paternalism

137 Ibid, 253-60. 
was the antithesis of individualism. Equally, it shows the extent to which the goal of making workers responsible and independent were predicated on the stereotype that workers were inherently lazy, feckless, and in need of organization by others-a form of organization, which, in the case of Fordson, made independence available to a select few male, permanent, and thrifty employees. The implication, here, is that antisocialism and pro-Conservatism were not just two, unrelated appeals made by interwar conservatives, but rather two sides to the same coin. ${ }^{138}$

Most importantly, though, the history of the Fordson experiment and its form of conservative modernism speaks to the experimental and even radical potential for this form of conservatism-particularly in relation to the English countryside. This argument about the radical nature of interwar conservatism stands in direct contrast to the work of David Matless in his pathbreaking analysis of Britain's preservationist movement and the Landscape of Englishness they helped construct in the interwar and immediate postwar period. ${ }^{139}$ In it, Matless argues that preservationist planning-as represented in groups like the Campaign for the Protection of Rural England, with their commitment to restoring rural England through modernization-was out of tune with the political philosophy of Baldwinite conservatism. Matless suggests that Baldwin's “Conservative Englishness of social harmony, constitutional caution, organic culture and pastoral community is a site for neither anger nor action." 140 While Matless is undeniably correct in suggesting that Conservatives were often unwilling to use the state to remake the English countryside, the project of the Fordson Estate reveals there was much more action involved in preservationism and the creation of a "landscape of Englishness" than simply planning or legislative activity. Rather, Conservatives like Perry could turn to their own factories, offices, shops, and farms and use their own means and resources to create the rural England of their conservative imaginations. To use a term that would have infuriated Conservatives, this was conservatism as praxis not just political philosophy. In 1924 Baldwin stated, "I refrain, as I always have done, from displaying visions of a new heaven and a new earth emanating from Whitehall," but this did not mean that other Conservatives did not seek to create such utopian conditions. Rather, they, like he, simply recognized that Whitehall was not always the correct vehicle for them. ${ }^{141}$

\footnotetext{
${ }^{138}$ Williamson, Stanley Baldwin, 352-53.

${ }^{139}$ Matless, Landscape and Englishness.

140 Ibid., 30.

${ }^{141}$ As quoted in Ramsden, Age of Balfour and Baldwin, 212.
} 